\title{
Requirement for Early-Generated Neurons Recognized by Monoclonal Antibody Lot1 in the Formation of Lateral Olfactory Tract
}

\author{
Yasufumi Sato, ${ }^{1}$ Tatsumi Hirata, ${ }^{1}$ Masaharu Ogawa, ${ }^{2}$ and Hajime Fujisawa ${ }^{1}$ \\ ${ }^{1}$ Division of Biological Science, Nagoya University Graduate School of Science, Chikusa-ku, Nagoya 464-8602, Japan, \\ and 2Department of Physiology, Kochi Medical School, Kochi 783-8505, Japan
}

During development, mitral cells, the main output neurons of the olfactory bulb, project axons into a very narrow part of the telencephalon and form an axonal bundle called the lateral olfactory tract (LOT). The present study shows that before the first mitral cell axons elongate, the LOT position is already marked with a subset of early-generated neurons that are recognized by monoclonal antibody lot1 (lot cells). Mitral cell axons choose the lot cell position for their growth pathway and maintain a close contact with the cells until LOT formation is completed. Ablation of lot cells prevented LOT formation in organotypic culture. These results suggest that lot cells are "guidepost cells" for mitral cell axons.

Key words: lot cell; lateral olfactory tract; mitral cell; monoclonal antibody; guidepost; Cajal-Retzius cell; development
During development of the nervous system, axons often navigate for long distances and reach their appropriate targets in highly stereotyped manners (Dodd and Jessell, 1988; Goodman and Shatz, 1993; Tessier-Lavigne and Goodman, 1996). Transient interactions between growing axons and specialized cells in their pathways are crucial for proper guidance of the axons (Ghosh, 1997). For instance, "guidepost cells" exist in the limb buds of grasshopper embryos and direct pioneer axons to the correct pathway (Bentley and Keshishian, 1982; Bentley and Caudy, 1983). The floor plate of the spinal cord might be another class of specialized cells that guide commissural axons by secretion of chemoattractants (Kennedy et al., 1994; Serafini et al., 1994). In the neocortex, subplate neurons, transient neurons during development, have been shown to serve as intermediate targets for thalamocortical axons and direct pathway choice (Ghosh et al., 1990; Ghosh and Shatz, 1992, 1993).

Mitral cell axons, the major efferents of the olfactory bulb, caudally elongate in a very narrow part of the lateral telencephalon and make a stereotyped turn toward the amygdala (Schwob and Price, 1984; Brunjes and Frazier, 1986; Shipley et al., 1995) (see Fig. 1A). The axons collectively form a discrete fiber bundle called the lateral olfactory tract (LOT). We previously performed organotypic co-culture of the olfactory bulbs with various parts of the mouse telencephalon and showed that mitral cell axons are guided by biochemical cues that are strictly localized in the telencephalon (Sugisaki et al., 1996). Our previous study also suggested that intrinsic cells in the telencephalon play a directional role in guidance of mitral cell axons (Sugisaki et al., 1996).

\footnotetext{
Received May 12, 1998; revised July 13, 1998; accepted July 13, 1998.

This work was supported by grants from the Ministry of Education and Science and Culture and Core Research for Evolution Science and Technology (CREST) of Japan Science and Technology Corporation (JST). Y.S. is a research fellow of the Japan Society for the Promotion of Science. We thank Dr. Kazuaki Yoshikawa of the Institute for Protein Research, Osaka University, for the generous gift of anti-nestin antibody, and Dr. Joel Glover of Oslo University for helpful advice.

Correspondence should be addressed to Dr. Tatsumi Hirata, Division of Biological Science, Nagoya University Graduate School of Science, Chikusa-ku, Nagoya 464-8602, Japan.

Copyright (ㄷ) 1998 Society for Neuroscience $\quad 0270-6474 / 98 / 187800-11 \$ 05.00 / 0$
}

However, there have been no reports concerning such guiding cells in the telencephalon.

In the present study, we screened for monoclonal antibodies (mAbs) against the developing mouse olfactory cortex and obtained one interesting antibody, which was named mAb lot1. The cells recognized by mAb lot1 (lot cells) were early-generated neurons and constituted a cellular array in the presumptive LOT position of the embryonic telencephalon, before the first mitral cell axons projected out from the olfactory bulb. Mitral cell axons selectively grew along the lot cell array in vivo and in co-culture. Ablation of lot cells in organotypic cultures caused mitral cell axons to stall in the position lacking these cells. These results suggest that lot cells function as guidepost cells for mitral cell axons.

\section{MATERIALS AND METHODS}

Animals. ICR strain mice and Wistar rats were purchased from Chubu Kagaku Shizai (Nagoya, Japan). The day on which a vaginal plug was detected was designated embryonic day 0.5 (E0.5). The dams were deeply anesthetized with ether, and the embryos were dissected out in HBSS. Stages of all embryos were then determined again according to the definition by Theiler (1989).

Immunization and production of hybridomas. Approximately 30 olfactory bulbs of E14.5 mouse embryos were suspended in $0.1 \mathrm{ml}$ of HBSS, triturated by passages through a 27 gauge needle, and injected into the left hindfoot pad of rats. Rats were immunized four times at 3 week intervals. Three days after the final booster immunization, lymphocytes from the left inguinal and popliteal lymph nodes were fused with myeloma cells (P3X63Ag8U1), as described previously (Oi and Herzenberg, 1981; Takagi et al., 1987). The supernatants of hybridoma cultures were screened immunohistochemically on sections of E14.5 mouse telencephalons. For cloning, single cells were picked up using glass capillaries with a fine tip and transferred into each well of 96-well culture plates (Becton Dickinson, Franklin Lakes, NJ) containing DMEM (Nissui, Tokyo, Japan) supplemented with $10 \%$ fetal bovine serum (JRH Bioscience, Lenexa, KS) and 10\% hybridoma cloning factor (Igen, Gaithersburg, MD).

Immunohistochemistry. Mouse embryonic brains were fixed with $4 \%$ paraformaldehyde (PFA) in PBS overnight at $4^{\circ} \mathrm{C}$, immersed in $20 \%$ sucrose in PBS overnight, and then frozen in OCT compound (TissueTek; Sakura Finetechnical, Tokyo, Japan). Coronal sections $14 \mu \mathrm{m}$ thick were cut on a cryostat and placed on glass slides coated with poly-L-lysine (Sigma, St. Louis, MO). The sections were incubated with $10 \mathrm{~mm}$ Tris-HCl, pH 7.4, $130 \mathrm{~mm} \mathrm{NaCl}, 0.1 \%$ Tween 20 (TBST) for $10 \mathrm{~min}$ to 
remove the OCT compound, and then with supernatants of hybridoma cultures for $1 \mathrm{hr}$. Bound antibodies were visualized with $\mathrm{Cy} 3$-labeled anti-rat Ig antibody (1:500; Amersham, Buckinghamshire, UK).

Whole-mount immunostaining was performed according to the procedures described previously (Sugisaki et al., 1996). Briefly, telencephalons and cultures were fixed with $4 \%$ PFA in PBS for $12 \mathrm{hr}$ at $4^{\circ} \mathrm{C}$ and incubated in 5\% skim milk/TBST for $1 \mathrm{hr}$ to block nonspecific binding of antibodies. The specimens were then incubated with mAb lot1 (10 $\mu \mathrm{g} / \mathrm{ml}$ ), which had been affinity-purified by passage through a protein A column (Affigel Protein A MAPs kit, Bio-Rad, Hercules, CA). The bound antibodies were visualized with $\mathrm{Cy} 3$ - or $\mathrm{Cy}$-labeled anti-rat Ig antibody (1:500; Amersham).

In some immunostainings, rabbit anti-neuropilin- 1 antibody $(2 \mu \mathrm{g} / \mathrm{ml})$, mouse anti-MAP2 (1:500; Sigma), mouse anti-reelin mAb CR-50 [2 $\mu \mathrm{g} / \mathrm{ml}$; Ogawa et al. (1995); D'Arcangelo et al. (1997)], mouse antineurofilament mAb 2H3 (1:100 hybridoma supernatant; Developmental Studies Hybridom Bank, Iowa, IA), rabbit anti-calretinin antibody (1: 100; Chemicon International Inc., Temecula, CA), or rabbit anti-nestin antibody (1:500; a generous gift from Dr. K. Yoshikawa, Osaka University) was used. As secondary antibodies, FITC-labeled anti-mouse Ig antibody (1:100; Amersham) or FITC-labeled anti-rabbit Ig antibody (1:100; Amersham) was used.

Anterograde labeling of olfactory bulb efferents with fluorescent dextran. Telencephalons were dissected out from mouse embryos and freed from the pia mater. Small shallow cuts were made in the olfactory bulbs or rostral telencephalons, and small crystals of fixable FITC- or rhodamineconjugated dextran (Molecular Probes, Eugene, OR) were immediately applied into the cuts as described previously (Forehand et al., 1994). The telencephalons were incubated in culture medium for $2 \mathrm{hr}$ at $37^{\circ} \mathrm{C}$ to fill the entire axons with the dye. The specimens were then fixed with $4 \%$ PFA in PBS and processed for whole-mount immunostaining with mAb lot1.

BrdU labeling and detection. Pregnant mice were injected intraperitoneally with 5-bromo-2-deoxyuridine (BrdU) solution at $3 \mathrm{mg}$ per mouse. Mouse embryos were dissected out from the dams at E14.5 and processed for frozen sectioning. The sections were first immunostained with mAb lot1 and Cy3-labeled anti-rat Ig antibody as described above, and then fixed again and treated with $4 \mathrm{~N} \mathrm{HCl}$ for $5 \mathrm{~min}$. After neutralization with 0.1 M Tris-HCl, pH 9.0, the sections were incubated with mouse antiBrdU antibody (1:100; Becton Dickinson) and then with FITC-labeled anti-mouse Ig antibody (1:200; Amersham).

Cultures. Organotypic culture was performed as described previously (Sugisaki et al., 1996). Briefly, E12.5 telencephalon hemispheres were dissected out, freed from the pia mater, and placed ventricular side down on collagen-coated membrane filters (Transwell-COL 3418, Costar, Cambridge, MA). In co-cultures, the olfactory bulbs were isolated from E13.5 telencephalons and combined with the LOT positions of E12.5 telencephalon strips (see Fig. 5A). The explants were cultured in DMEM/Ham's F12 medium (1:1 mixture; Nissui) containing 10\% fetal bovine serum at $37^{\circ} \mathrm{C}$ in an atmosphere containing $5 \% \mathrm{CO}_{2}$ for $2-3 \mathrm{~d}$. Olfactory bulbs were cultured according to the procedure of Hirata and Fujisawa (1997).

6-Hydroxydopamine treatment. Small squares of 4\% agarose gel $(\sim 500$ $\mu \mathrm{m}$ square and $100 \mu \mathrm{m}$ thick) were soaked with $8 \mathrm{~mm}$ 6-hydroxydopamine (6-OHDA) hydrobromide (Research Biochemicals International, Natick, MA) and $0.008 \%$ ascorbic acid in PBS. The agarose gels were placed in contact with E12.5 telencephalon surface with fine forceps for $2 \mathrm{~min}$ at room temperature (see Fig. 6A). After several washes with culture medium, the telencephalons were organotypically cultured for $2 \mathrm{~d}$ as described above. Agarose gel soaked with $0.008 \%$ ascorbic acid in PBS was used in control experiments.

\section{RESULTS}

\section{Production of mAb lot1}

Hybridoma cell lines were produced by fusion of mouse myeloma cells with lymphocytes from three immunized rats. Culture supernatants of approximately 2000 hybridoma lines were screened by immunostaining on sections of E14.5 mouse telencephalons. mAb lot1 was selected because this mAb specifically stained a cell subset around the LOT. None of the other hybridoma lines gave a similar staining pattern.

\section{Development of lot cells in telencephalon}

At E12.0, mAb lot1-positive lot cells first appeared on the telencephalon surface (Fig. $1 B$ ). mAb lot1 bound strongly to the perinuclear region and weakly to the cell membrane. This subcellular localization of the antigen made it difficult to follow the entire morphology of lot cells. However, close examination of the telencephalon, in particular in whole-mount preparations, showed that lot cells were typically fusiform in shape and had two processes that tangentially elongated along the telencephalon surface (Fig. $1 B, G$; see Fig. $6 C$ ). In addition to the morphological characteristics, lot cells exhibited a neuronal marker, microtubule-associated protein 2 (MAP2), indicating their neuronal phenotype (Fig. $1 C$ ).

Whole-mount immunostaining of the E12.0 telencephalon with mAb lot1 revealed a clear spatial distribution pattern of lot cells. The cell bodies constituted a broad band in the developing piriform cortex where the future site of LOT was included (Fig. $1 D)$. The lot cells were more abundant in the caudal telencephalon. Thus, the caudoventral end of the band became thick and reached the putative position of the amygdala. The lot cells that were situated in the ventral side of the band were packed, and their processes were aligned in the same direction, which seemed to correspond to the future direction of the LOT (Fig. 1E). The cells in the dorsal side were scattered and had more randomly oriented processes (Fig. 1E). Rostrally, lot cells showed a reduction in number and disappeared before reaching the rostral end of the telencephalon, where the olfactory bulb protrusion, a good landmark of the rostral-most telencephalon, was not yet prominent (Fig. 1D).

At E12.5, lot cells were more packed and arranged, and they constituted a thin cellular array that arched in the piriform cortex (Fig. $1 F$ ). Processes of lot cells, together with their cell bodies, aligned and oriented in the same direction, although tight fasciculation of the processes was not obvious (Fig. $1 G$ ). At this stage, the primitive olfactory bulb became prominent in the rostralmost telencephalon, and the lot cells became distributed in the developing olfactory bulb. Thus, the lot cell array stretched from the olfactory bulb to the amygdala and appeared to correspond to the future site of the entire LOT (Fig. $1 F$ ).

\section{Spatiotemporal relationship of lot cells and olfactory bulb efferents}

To examine the relationship between lot cells and LOT formation, the first axons from the olfactory bulb were traced. The axonal tracer dextran-FITC was injected into the rostral end of the E12.0 telencephalon. Although the majority of labeled cells did not have any axons, a few cells were equipped with short axons, probably the first efferents of the olfactory bulb (Fig. 2A). Among these axons, very few grew beyond the putative caudal limit of the olfactory bulb and made contact with lot cells in the telencephalon (Fig. 2A).

At E12.5, we injected dextran-FITC into the dorsal level of the developing olfactory bulb, because the first efferent neurons, mitral-like cells of the accessory olfactory bulb, were shown to develop in this position (Bayer, 1983). A few axons that projected out from the olfactory bulb were labeled (Fig. $2 B$ ). Immunostaining with $\mathrm{mAb}$ lot1 showed that these first olfactory bulb efferents selectively grew on the lot cell array (Fig. 2B). In 30 telencephalons examined, no labeled axons dropped out of the lot cell array.

At E13.5, more olfactory bulb efferents, including mitral cell axons from the main olfactory bulb, grew into the telencephalon 

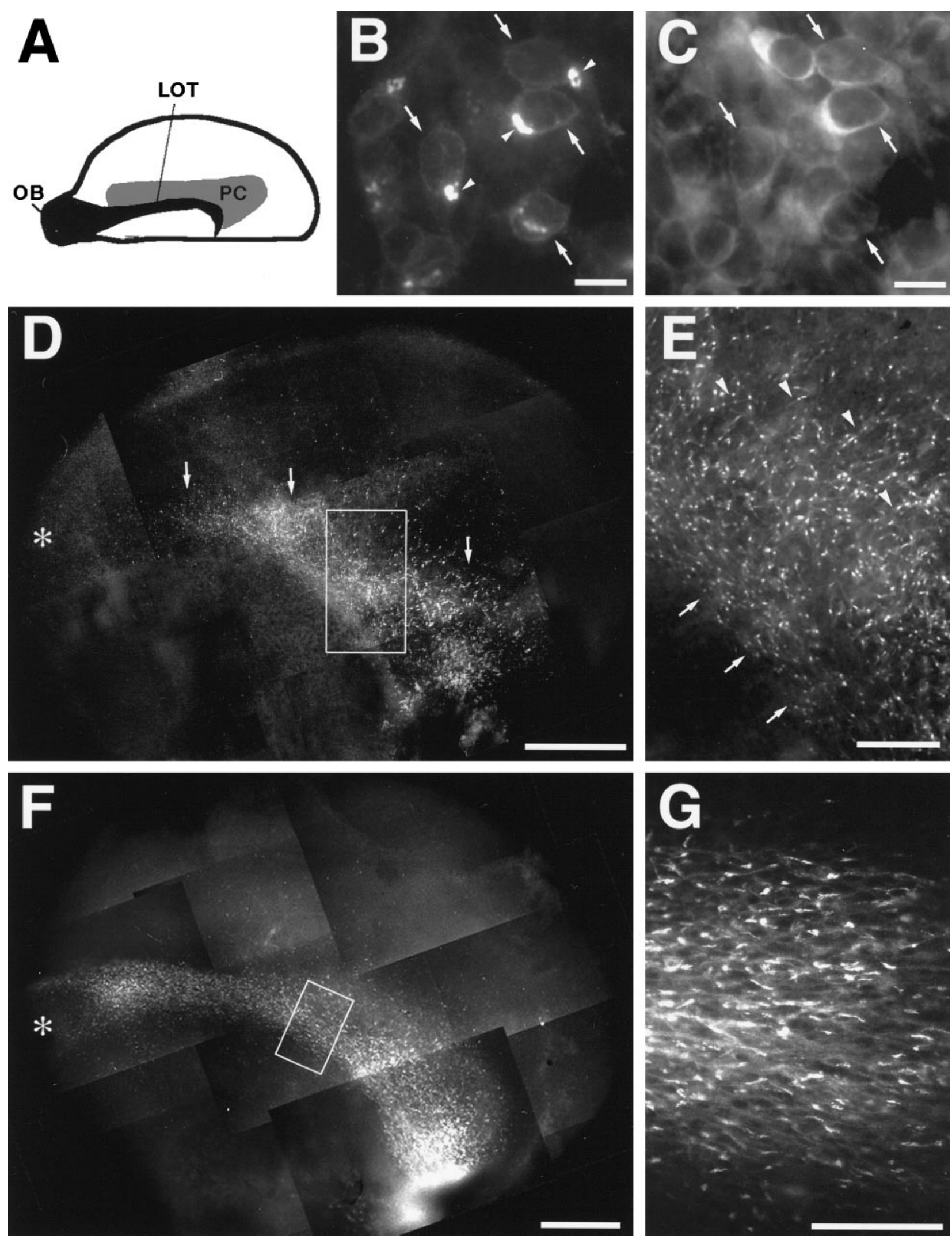

Figure 1. Lot cells in whole-mount preparations of telencephalons. $A$, A schematic diagram of the mouse lateral telencephalon at $\sim$ E14.5. Mitral cell axons preferentially elongate on the surface of the piriform cortex and form the LOT bundle. $L O T$, Lateral olfactory tract; $O B$, olfactory bulb; $P C$, piriform cortex. $B$, Lot cells in the E12.0 telencephalon. The lot cells (arrows) have tangentially oriented processes on the telencephalon surface. The $\mathrm{mAb}$ lot1 strongly binds to the perinuclear region of the cells (arrowheads). $C$, Anti-MAP2 immunostaining of the telencephalon in the field shown in $B$. The lot cells express MAP2 (arrows). D, Whole-mount immunostaining of the E12.0 telencephalon with mAb lot1. Arrows indicate the lot cell position. The putative position of the rostral-most telencephalon is indicated by an asterisk. E, Higher-magnification view of the (Figure legend continues) 

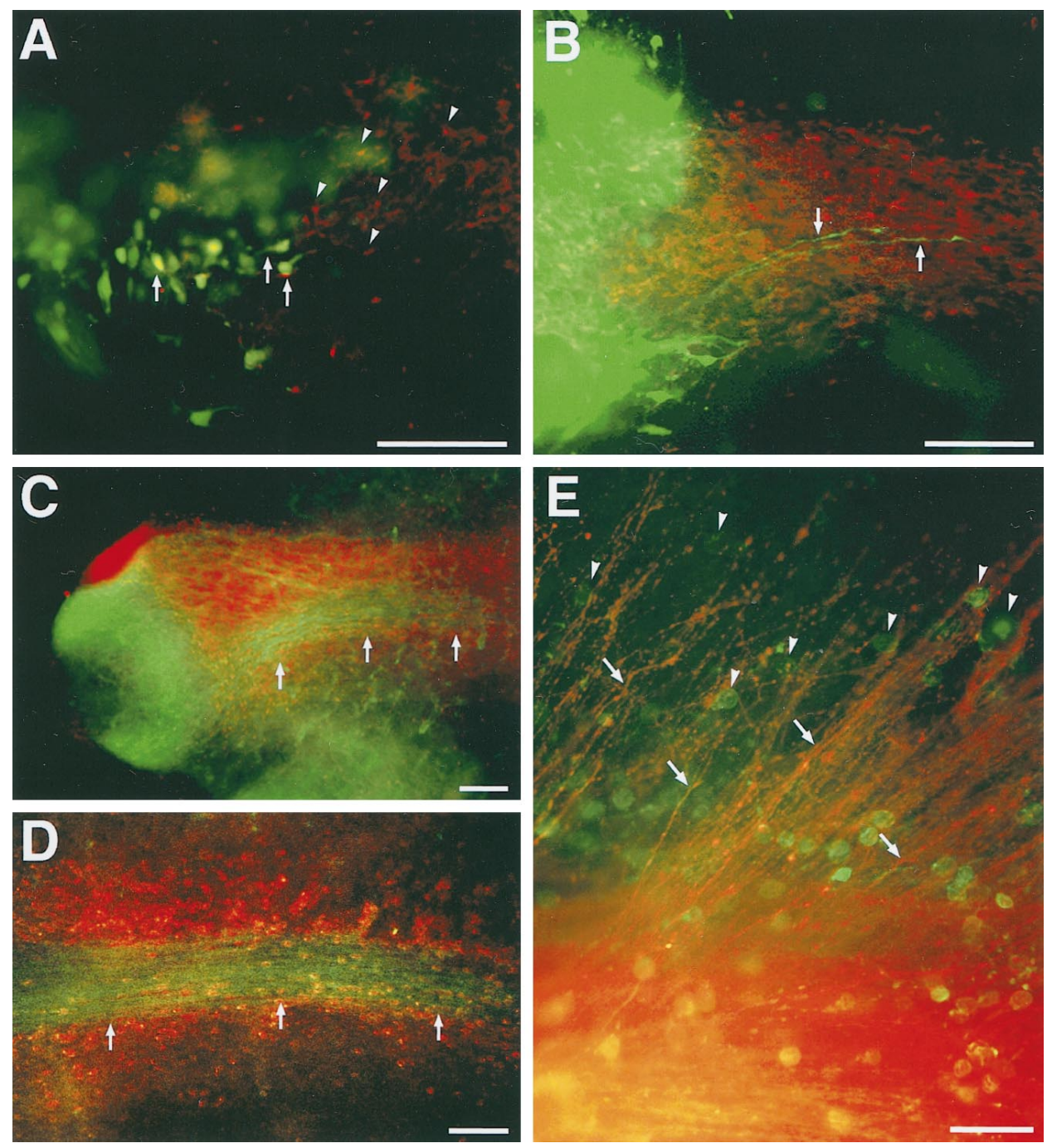

Figure 2. Lot cells and olfactory bulb efferents in whole-mount preparations. $A$, Dextran-FITC was injected into the rostral telencephalon at E12.0. The FITC-labeled cells (arrows) extend only short axons. Some lot cells (red) are indicated by arrowheads. B, Dextran-FITC was injected at E12.5. The FITC-labeled axons (arrows) preferentially elongate on the lot cell array. $C, D$, Double immunostaining of the E13.5 telencephalon with anti-neuropilin-1 antibody (green) and mAb lot1 (red). Photographs from the rostral telencephalon including the olfactory bulb $(C)$ and from a more caudal region of the telencephalon $(D)$. Mitral cell axons form the LOT bundle (arrows) in the middle of lot cell array. E, Rhodamine-labeled collateral branches and lot cells ( green) in the E16.5 telencephalon. Some lot cells (arrowheads) change their orientation and are intermingled with the collateral branches (arrows). Scale bars, $100 \mu \mathrm{m}$.

and formed a marked LOT bundle. From this stage, the LOT bundle could be visualized by immunostaining with an antibody against neuropilin-1, which is strongly expressed in mitral cells of the main olfactory bulb (Kawakami et al., 1996; Sugisaki et al., 1996). Whole-mount double immunostaining of the telencephalon with mAb lot1 and anti-neuropilin-1 antibody clearly showed that the discrete LOT bundle was formed on the lot cell array (Fig. 2C,D). The $\operatorname{lot}^{+}$cells were accordingly redistributed to surround the LOT bundle, as if the cells were pushed aside by the bundle. Nevertheless, $\operatorname{lot}^{+}$cells and their processes still kept the right arrangement along the LOT direction (Fig. 2C,D).

The lot cells were most numerous at E14.5 but still confined to the vicinity of the LOT, which was markedly developed in the telencephalon (Fig. 3A). Thus, most lot cells were located in the most superficial layer of the piriform cortex, layer I (Fig. $3 B$ ). In the rostral telencephalon, many lot cells were distributed in the external plexiform layer of the accessory olfactory bulb (Fig. 3C). We could not correlate these cells with intrinsic cell types of the accessory olfactory bulb, which have been studied mainly in adult animals (Matsutani et al., 1988; Takami and Graziadei, 1991; Shipley et al., 1995). The lot cells were also distributed in the external plexiform layer of the main olfactory bulb, but the number of these cells was much smaller than that in the accessory olfactory bulb (Fig. 3C). The lot cells in the main olfactory bulb also did not correspond to the described criteria for intrinsic cell types (Hinds, 1972; Hinds and Ruffett, 1973; Macrides and Schneider, 1982; Bayer, 1983; Brunjes and Frazier, 1986). In the olfactory bulb, mitral cell axons elongated through the inner plexiform layer, which was situated deeper than the external plexiform and mitral cell layers (Fig. $3 C$ ), before joining the LOT in the telencephalon surface. Thus, mitral cell axons grew in the layer internal to lot cells in the olfactory bulb (Fig. 3C), whereas they grew in the layer superficial to lot cells within the telencephalon (Fig. 3B). In the transition area where the relative positions of lot cells and mitral cell axons were reversed, mitral cell axons formed small fascicles and passed through lot cell clusters (Fig. 3D).

At E16.5, the intensity of immunostaining with mAb lot1 be-

$\leftarrow$

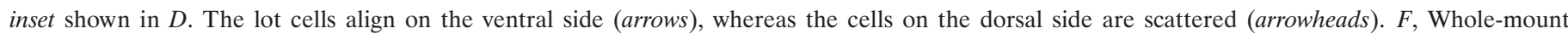

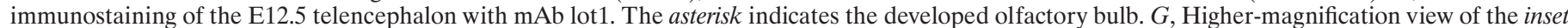

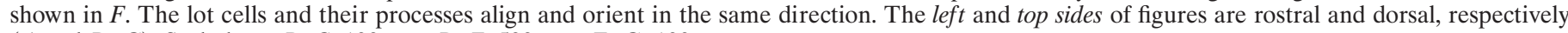
( $A$ and $D-G$ ). Scale bars: $B, C, 100 \mu \mathrm{m} ; D, F, 500 \mu \mathrm{m} ; E, G, 100 \mu \mathrm{m}$. 

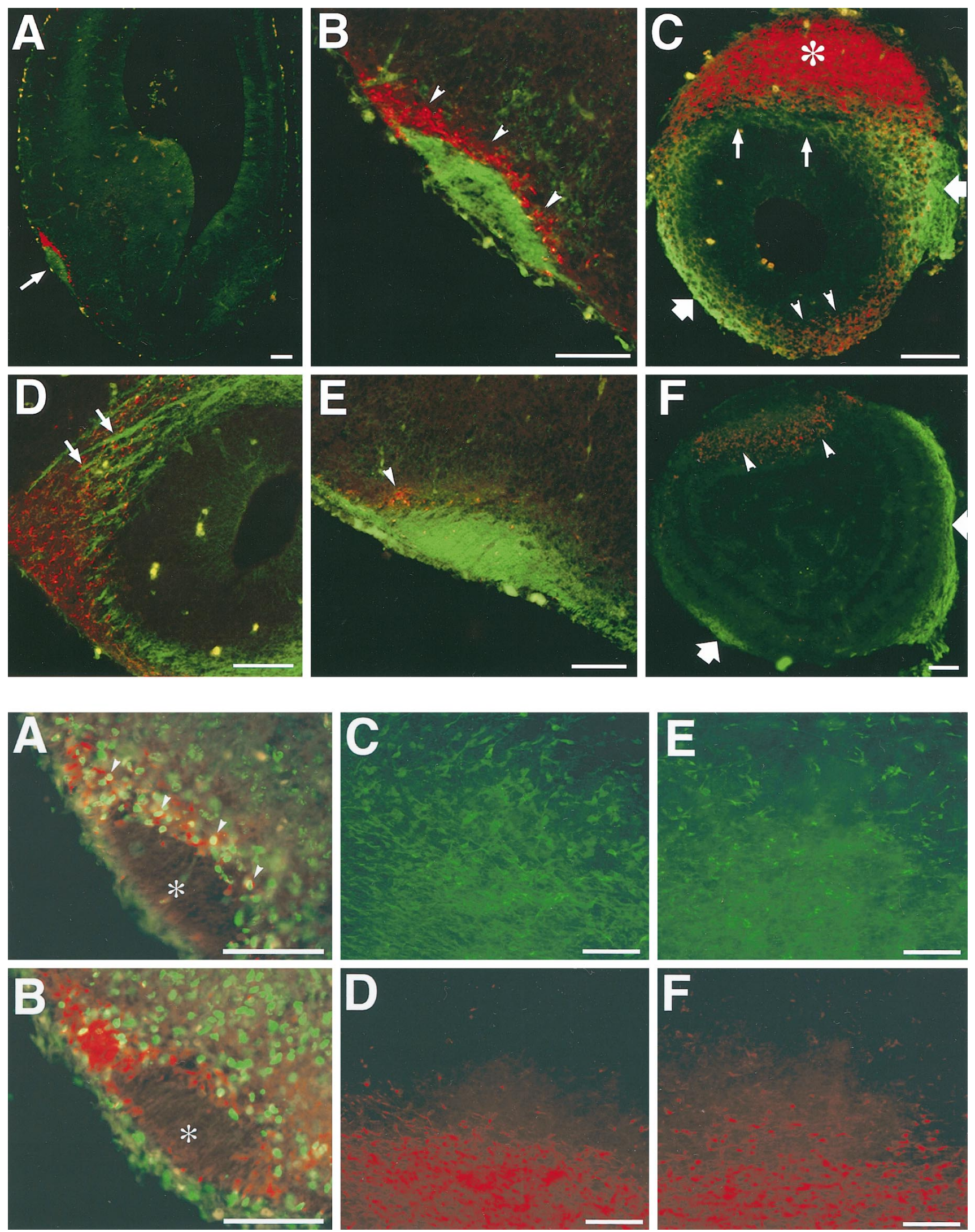

Figure 3. Top. Lot cells and mitral cell axons in telencephalon sections. All sections were double-immunostained with $\mathrm{mAb}$ lot1 (red) and anti-neuropilin-1 antibody (green). A, The E14.5 telencephalon. The LOT is indicated by an arrow. B, High-magnification view of the LOT in $A$. The lot cells (arrowheads) are located beneath the LOT. $C$, The E14.5 olfactory bulb. The lot cells are markedly concentrated in the accessory olfactory bulb (asterisk). The external plexiform layer of the main olfactory bulb also contains a few lot cells (arrowheads). Mitral cell axons (small arrows) grow in the layer subjacent to lot cells. Large arrows indicate the olfactory nerves that are also neuropilin-1-positive. D, The caudal end of the E14.5 olfactory (Figure legend continues) 
came weaker as compared with earlier stages. However, lot cells were still identified as a cellular array beside the LOT. At this stage, mitral cell axons begin to give off collateral branches from the LOT over the dorsolateral level of the piriform cortex (Sugisaki et al., 1996; Hirata and Fujisawa, 1998). Some lot cells around this position changed their orientation, dispersed from the cellular array, and intermingled with the collateral branches of mitral cell axons (Fig. 2E). The dispersion of lot cells was spatiotemporally a little behind the spread of collateral branches. The majority of lot cells still remained in the vicinity of the LOT even after vast collateral extension (Fig. $2 E$ ).

After E18.5, mAb lot1 immunostaining rapidly became fragmentary and obscure. In the piriform cortex, only punctate staining was observed around the LOT (Fig. 3E). Although the expression of lot 1 antigen lasted for a relatively long period in the accessory olfactory bulb, the immunostaining also became fragmentary (Fig. $3 F$ ), and it totally vanished by postnatal day 6 .

\section{Lot cells are the earliest-generated neurons}

Because lot cells were neurons, we determined the birth date of lot cells. The thymidine analog BrdU was injected into pregnant mice in which embryos were at stages E9.0, E9.5, E10.5 or E11.5, and then the cells heavily labeled with BrdU were detected at E14.5 by immunohistochemistry. When BrdU was injected at E9.0, no cells in the piriform cortex were heavily labeled (data not shown). When BrdU was injected at E9.5 or E10.5, a substantial number of cells in the superficial layer of the piriform cortex incorporated BrdU (Fig. 4A). Double immunolabeling showed that lot cells were BrdU-labeled (Fig. 4A). The BrdU injection at E11.5 labeled few lot cells and many lot1-negative cells in deeper layers of the piriform cortex (Fig. 4B). These results indicated that lot cells are the earliest-generated neurons in the piriform cortex.

Cajal-Retzius cells are early-generated neurons in the telencephalon that are situated in the most superficial layer of cortical plate and have tangentially oriented processes (Derer and Derer, 1990). To test whether lot cells and Cajal-Retzius cells exhibited common characteristics, expressions of two Cajal-Retzius cell markers, a calcium binding protein calretinin (Condé et al., 1994; Del Río et al., 1995) and extracellular matrix protein reelin (D’Arcangelo et al., 1995, 1997; Ogawa et al., 1995), were investigated immunohistochemically. Both calretinin- and reelinexpressing cells were uniformly scattered across the entire telencephalon surface, including the neocortex and piriform cortex (Fig. 4C,E). These observations were in marked contrast to the LOT-specific distribution of lot cells (Fig. 4D,F). At E14.5, about half of the lot cells expressed calretinin, whereas only a few expressed reelin. These results indicated that lot cells and CajalRetzius cells exhibit some characteristics in common but do not belong to the same cell group.

\section{Lot cell array is the sole pathway for mitral cell axons in co-culture}

Previous organotypic co-culture experiments showed that mitral cell axons penetrated into telencephalon fragments only when the olfactory bulbs were exactly combined with the presumptive LOT positions (Sugisaki et al., 1996). Because the presumptive LOT position was shown to be populated with lot cells, the relationship between lot cells and axonal ingrowth of mitral cells in co-culture was analyzed. We co-cultured E13.5 olfactory bulbs with E12.5 LOT positions for $3 \mathrm{~d}$ (Fig. $5 A$ ) and doubly immunostained the co-cultures with mAb lot 1 and anti-neuropilin-1 antibody.

Mitral cell axons penetrated into the telencephalon fragments only through the contact point with lot cell array (Fig. 5B,C). Detours of the axons from other points never occurred. Further elongation of mitral cell axons in the telencephalon was also limited to the position of lot cell array (Fig. $5 B, C$ ). When there was a small gap between the olfactory bulb and lot cell array, mitral cell axons never penetrated into the telencephalon fragments (data not shown).

\section{Ablation of lot cells prohibits LOT formation}

To assess the involvement of lot cells in LOT formation more directly, we deleted lot cells in the telencephalon. Because mAb lot1 only weakly binds the cell surface in unfixed tissues, we were not able to kill lot cells using this mAb, and instead used local application of 6-OHDA, which had been used to specifically kill Cajal-Retzius cells (Del Río et al., 1997; Supèr et al., 1997). Small pieces of agarose gel soaked with 6-OHDA solution were placed on the E12.5 telencephalon surface for $2 \mathrm{~min}$ (Fig. 6A). The telencephalon hemispheres were then washed with culture medium and cultured on membrane filters for $2 \mathrm{~d}$. This treatment resulted in marked loss of lot cells: more than $90 \%$ of lot cells in the treated area had disappeared in the $2 \mathrm{~d}$ (Fig. 6D). Many of the lot cells that remained showed picnotic figures and appeared to be dying (Fig. 6E). Treatment with agarose gel containing vehicle solution did not lead to any loss of lot cells (Fig. 6B,C).

To test whether the 6-OHDA treatment specifically ablated lot cells, we examined the effects of the reagent on the other cells in the telencephalon. Anti-neurofilament monoclonal antibody $2 \mathrm{H} 3$ (mAb 2H3) did not bind to lot cells themselves, but bound to neuronal subsets that were situated caudolaterally next to the lot cell array (Fig. 7A,B). The 6-OHDA treatment did not affect these $\mathrm{mAb} 2 \mathrm{H} 3$-positive neurons (Fig. 7C,D). We also examined MAP2 expression and nestin expression in the 6-OHDA-treated telencephalon. MAP2 was expressed in the surface region of the 6-OHDA-treated telencephalon as in the untreated controls (Fig. $7 E, H)$. Radial glial fibers expressing nestin were also unaffected by the treatment: end feet of the fibers reached the surface of the putative LOT position (Fig. $7 F, I$ ). Finally, although there were a few shrunken nuclei of lot cells around the LOT position, most of

\footnotetext{
bulb. Mitral cell axons (arrows) make small fascicles and pass through lot cell clusters. $E$, The E18.5 piriform cortex. Only fragmentary staining with mAb lot 1 is seen around the LOT (arrowhead). $F$, The olfactory bulb of a postnatal day 0 mouse. Faint staining with mAb lot 1 remains in the accessory olfactory bulb (arrowheads). At this stage, neuropilin-1 is expressed solely by olfactory nerves (large arrows). The left and top sides of figures are lateral and dorsal, respectively. Scale bars, $100 \mu \mathrm{m}$.

Figure 4. Bottom. Early generation of lot cells. $A, B$, BrdU was injected at E10.5 $(A)$ or E11.5 $(B)$, and cells incorporating BrdU ( green) were detected at E14.5. The lot cells (red) incorporated BrdU in $A$ (arrowheads) but not in B. Asterisks indicate the LOT positions. $C$, $D$, Whole-mount immunostaining of the E13.5 telencephalon with anti-calretinin antibody $(C)$ and mAb lot1 $(D)$ in the same field. $E$, $F$, Whole-mount immunostaining of the E13.5 telencephalon with anti-reelin mAb CR-50 $(E)$ and mAb lot1 $(F)$ in the same field. The calretinin- and reelin-positive cells are uniformly distributed across the telencephalon surface including the neocortex (the top third of the figures), whereas lot cells are limited to the LOT position (the bottom third of the figures). Scale bars, $100 \mu \mathrm{m}$.
} 

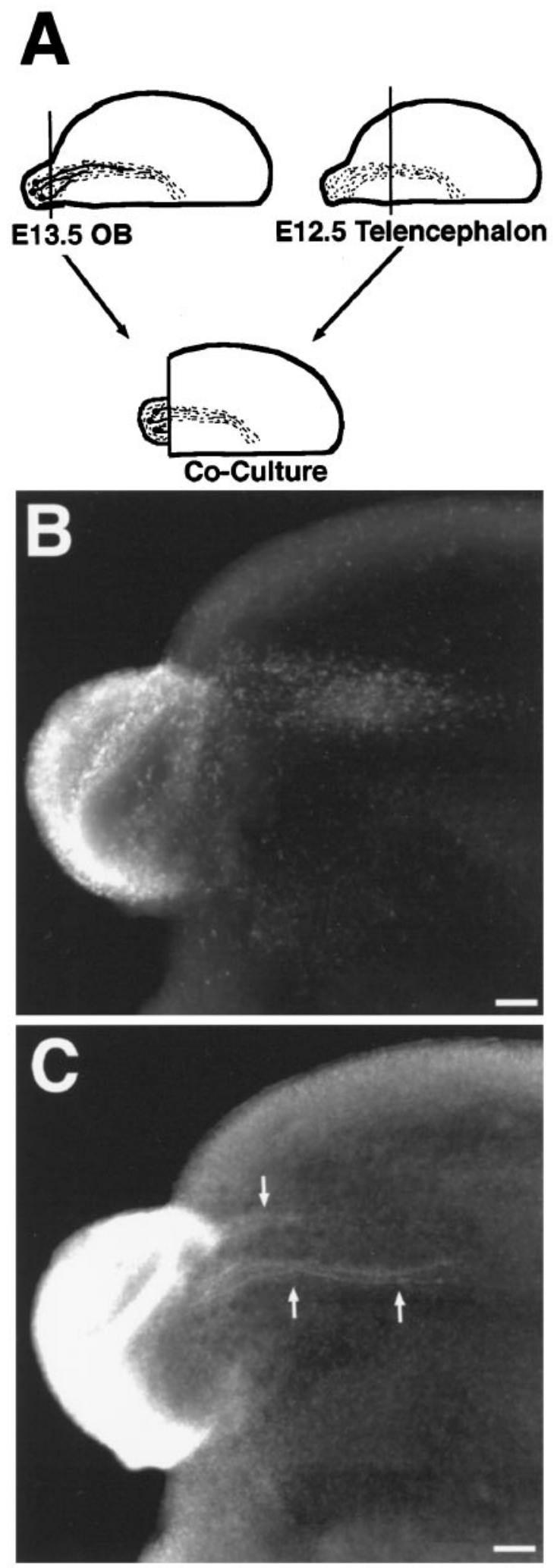

Figure 5. Lot cells and mitral cell axons in organotypic co-culture. $A, \mathrm{~A}$ schematic diagram of the co-culture procedure. The cut edge of the E13.5 olfactory bulb was combined with the presumptive LOT position of the E12.5 telencephalon fragment. The pair of explants was co-cultured for 3 d. $B, C$, The co-cultures were double-immunostained with mAb lot1 (B) and anti-neuropilin-1 antibody $(C)$. Mitral cell axons $(C$, arrows) grow into the telencephalon strip from the contact point with lot cells and selectively elongate on the lot cell array. Scale bars, $100 \mu \mathrm{m}$. the cells appeared healthy in the 6-OHDA-treated telencephalon, and no debris or scars were observed (Fig. $7 G, J$ ). These observations indicate that 6-OHDA treatment ablates lot cells without affecting the other major cell population, although some loss of Cajal-Retzius cells might be accompanied.

To determine whether the lot cell ablation affected guidance of mitral cell axons, the telencephalon hemispheres cultured for $2 \mathrm{~d}$ after 6-OHDA treatment were immunostained with antineuropilin-1 antibody. In the control telencephalon that had been treated with vehicle solution, mitral cell axons grew on the lot cell array and formed a LOT-like bundle during culture (Figs. $6 F, G$, $7 E-G)$. On the other hand, in all the 6-OHDA-treated telencephalons, mitral cell axons abruptly stalled in the piriform cortex where lot cells were absent (Fig. 6H,I). In these specimens, a small number of mitral cell axons occasionally strayed from the other axons and grew for a short distance (Fig. $6 H$ ). These axons were associated with lot cells that remained after 6-OHDA treatment, and often connected to small islands of lot cells (Fig. 6D).

The 6-OHDA treatment did not seem to toxically affect mitral cells themselves, because mitral cell axons grew normally to the point where lot cells were absent (Fig. 6H,I). Furthermore, when the olfactory bulbs were treated directly with 6-OHDA and then cultured on poly-lysine-coated culture dishes, neurite outgrowth of the mitral cells occurred to the same extent as that in the untreated olfactory bulbs (data not shown).

\section{DISCUSSION}

In the present study, we demonstrated that the LOT position of the mouse telencephalon was populated by a specific cell subset that was recognized by mAb lot1, i.e., lot cells. The lot cells were the earliest-generated neurons in the piriform cortex and exhibited some properties common to other early-generated neuronsCajal-Retzius cells-although these cells appeared to belong to different cell groups. The LOT-specific distribution of lot cells preceded the onset of elongation of the first mitral cell axons, and the very first axons from the olfactory bulb grew exactly on the surface of lot cells.

Our previous organotypic culture experiments have suggested the existence of intrinsic telencephalon cells that guide mitral cell axons by strictly localized interactions (Sugisaki et al., 1996). The distribution of lot cells seems to fulfill the criteria for the intrinsic telencephalon cells. First, lot cells were localized in the LOT position by stage E12.0, when the guiding cues for mitral cell axons first emerged in the telencephalon. Second, mitral cell axons in vivo always grew in the lot cell position and were closely associated with lot cells. Thus, the lot cells are the intrinsic telencephalon cells that make contact exclusively with growing mitral cell axons. Furthermore, in organotypic co-culture, mitral cell axons precisely chose the narrow lot cell array for their entry point and elongation pathway, but never penetrated into telencephalon strips without contact with lot cells. To ascertain the role of lot cells in mitral cell guidance, we ablated lot cells in organotypic cultures. Ablation resulted in stalling of mitral cell axons in the position where lot cells had been removed. A few mitral cell axons behaved as if they had found their growth pathway on the remnants of lot cells. Thus, in the absence of lot cells, the telencephalon appears to lose the guiding cues for mitral cell axons. In conclusion, we propose here the role of lot cells as guidepost cells for mitral cell axons.

Because guidepost cells were found in grasshopper embryos (Bentley and Keshishian, 1982; Bentley and Caudy, 1983), similar guiding mechanisms have been postulated in the mammalian 

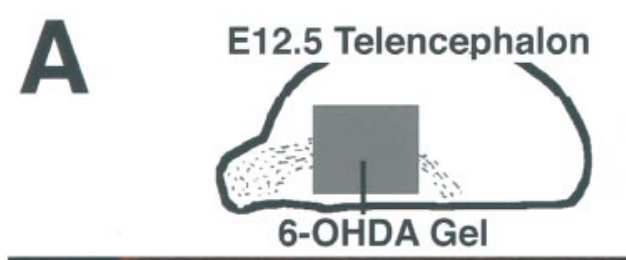

Wash \& Culture
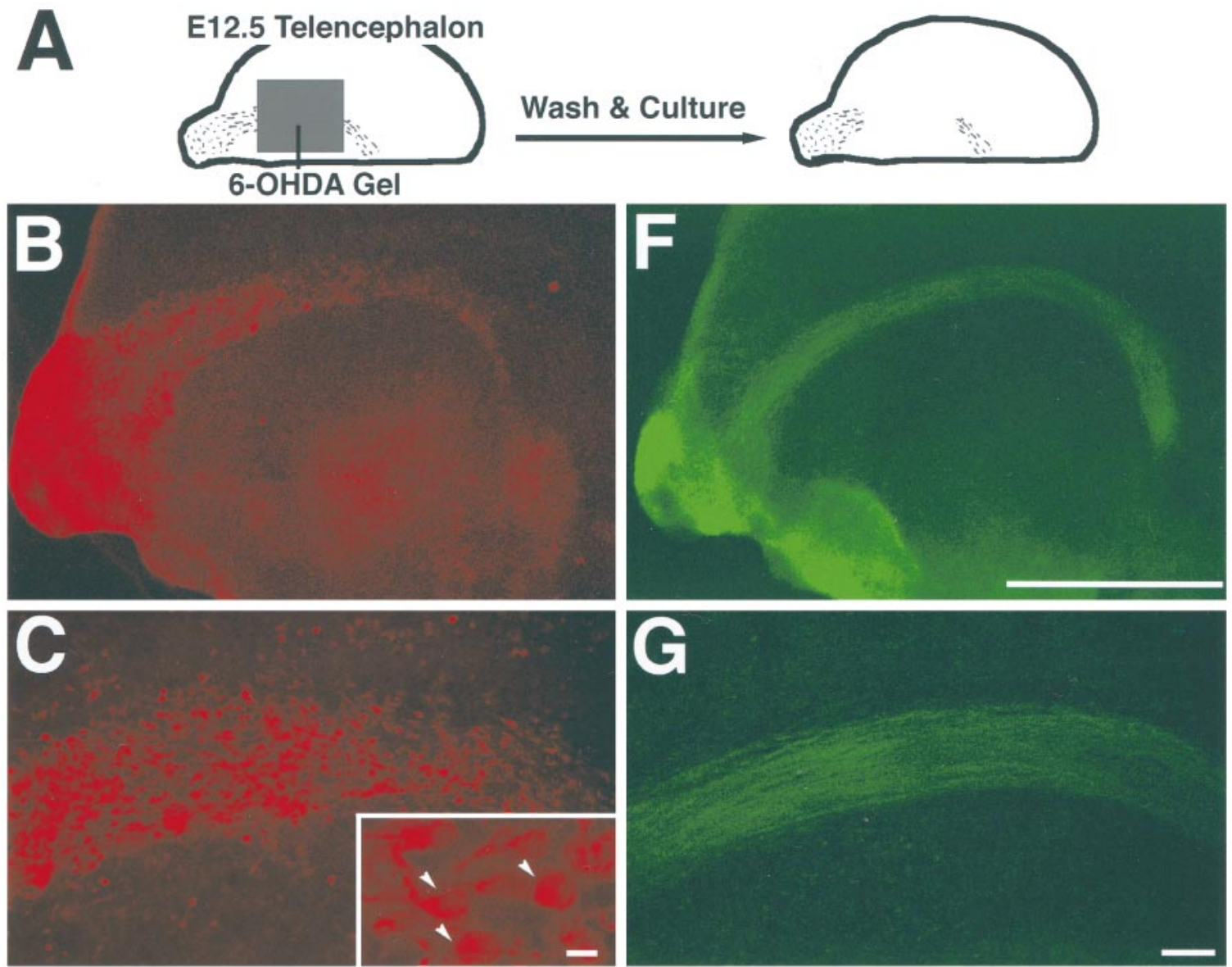

*
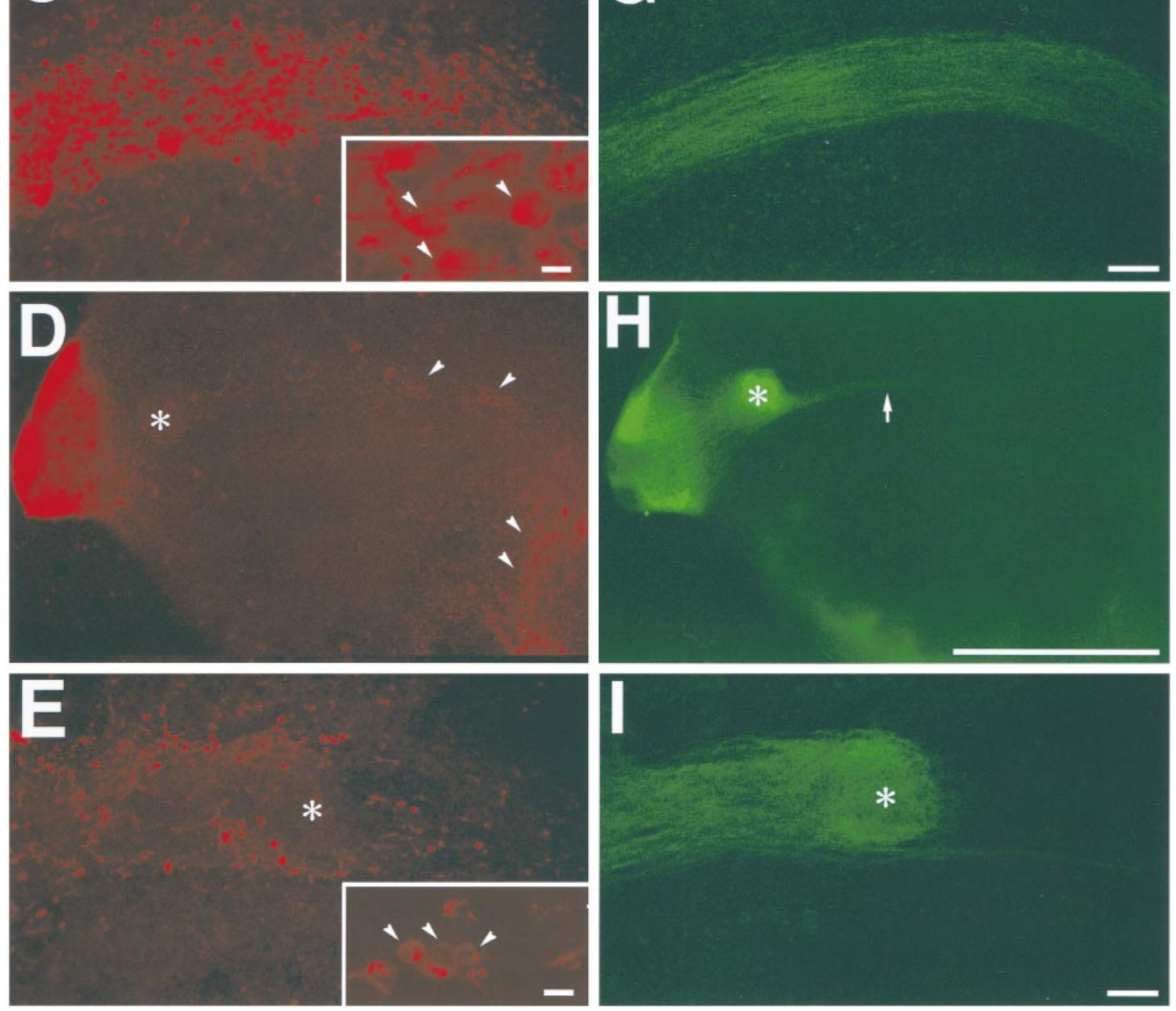

*

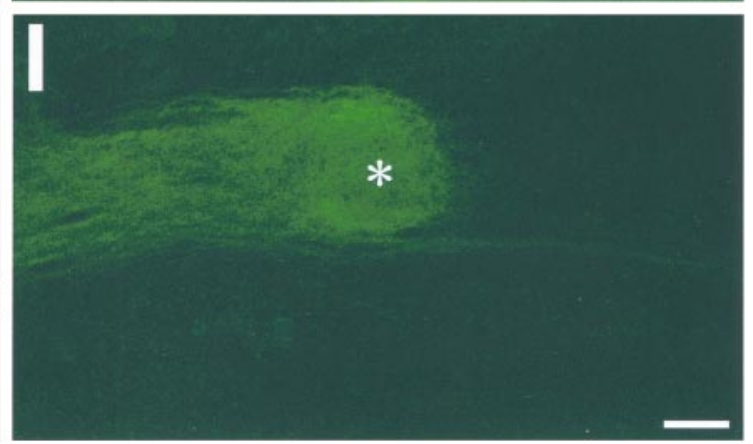

Figure 6. Effects of 6-OHDA treatment on lot cells and LOT formation. A, A schematic diagram of the protocol for 6-OHDA treatment. A square of agarose gel containing 6-OHDA was placed on the LOT position of E12.5 telencephalon hemisphere. The telencephalon was then washed and cultured for $2 \mathrm{~d}$. $B-I$, The telencephalons that were treated with vehicle solution $(B, C, F, G)$ or with 6-OHDA $(D, E, H, I)$ were immunostained with mAb lot1 $(B-E)$ and with anti-neuropilin-1 antibody $(F-J)$. Left and right panels in each row are the same fields. The insets in $C$ and $E$ are higher magnifications of the lot cells (arrowheads). The positions at which mitral cell axons stalled are shown by asterisks (D, E, H, I). Arrowheads in $D$ show lot cell clusters that remained after 6-OHDA treatment. The arrow in $H$ indicates relatively long mitral cell axons that grew on the remnants of lot cells. Scale bars: $F$, $H, J, 1 \mathrm{~mm} ; G, I, 100 \mu \mathrm{m}$; insets in $C, E, 10 \mu \mathrm{m}$. 

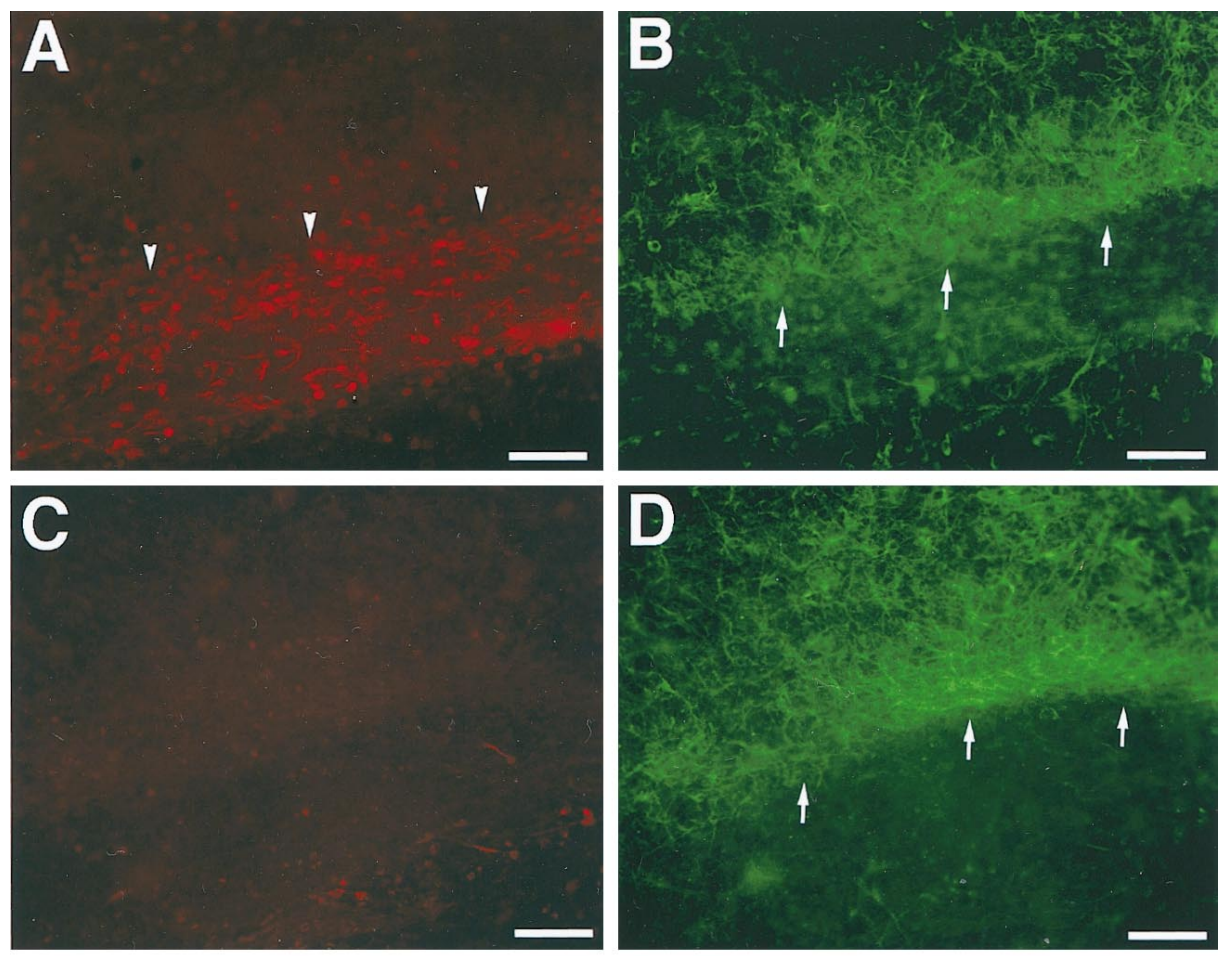

Figure 7. Effects of 6-OHDA treatment on the other cells in the telencephalon. $A-D$, The untreated $(A, B)$ and 6-OHDA-treated $(C, D)$ telencephalons were immunostained with mAb lot1 $(A, C)$ and anti-neurofilament $\mathrm{mAb}$ $2 \mathrm{H} 3(B, D)$ in whole-mount preparations. Left and right panels are the same field. The 6-OHDA treatment ablated lot cells $(A, a r-$ rowheads) but not $\mathrm{mAb} 2 \mathrm{H} 3$-positive neurons (B, D, arrows). E-J, Sections of untreated $(E-G)$ and 6-OHDA-treated telencephalons $(H-J)$ were stained with various antibodies. $E$, $H$, Sections double-immunostained with antiMAP2 mAb (green) and anti-neuropilin-1 antibody (red). The arrow in $H$ indicates the putative LOT position of the telencephalon. $F$, $I$, Sections stained with anti-nestin antibody. High-magnification views of the LOT positions (I, arrow) are shown in the insets. $G, J$, Sections stained with mAb lot1 (red) and Dapi (blue). Arrowheads indicate lot cells. The lot cells in $J$ have shrunken nucleoli and appear to be dying. The LOT bundle is formed in the untreated telencephalon only ( $E-G$, asterisks). The left and right sides of the figures show the pial and ventricular sides of the telencephalon, respectively $(E-J)$. Scale bars: $A-E, H, 100$ $\mu \mathrm{m}$; insets in $F$ and $I$, and $G, J, 10 \mu \mathrm{m}$.
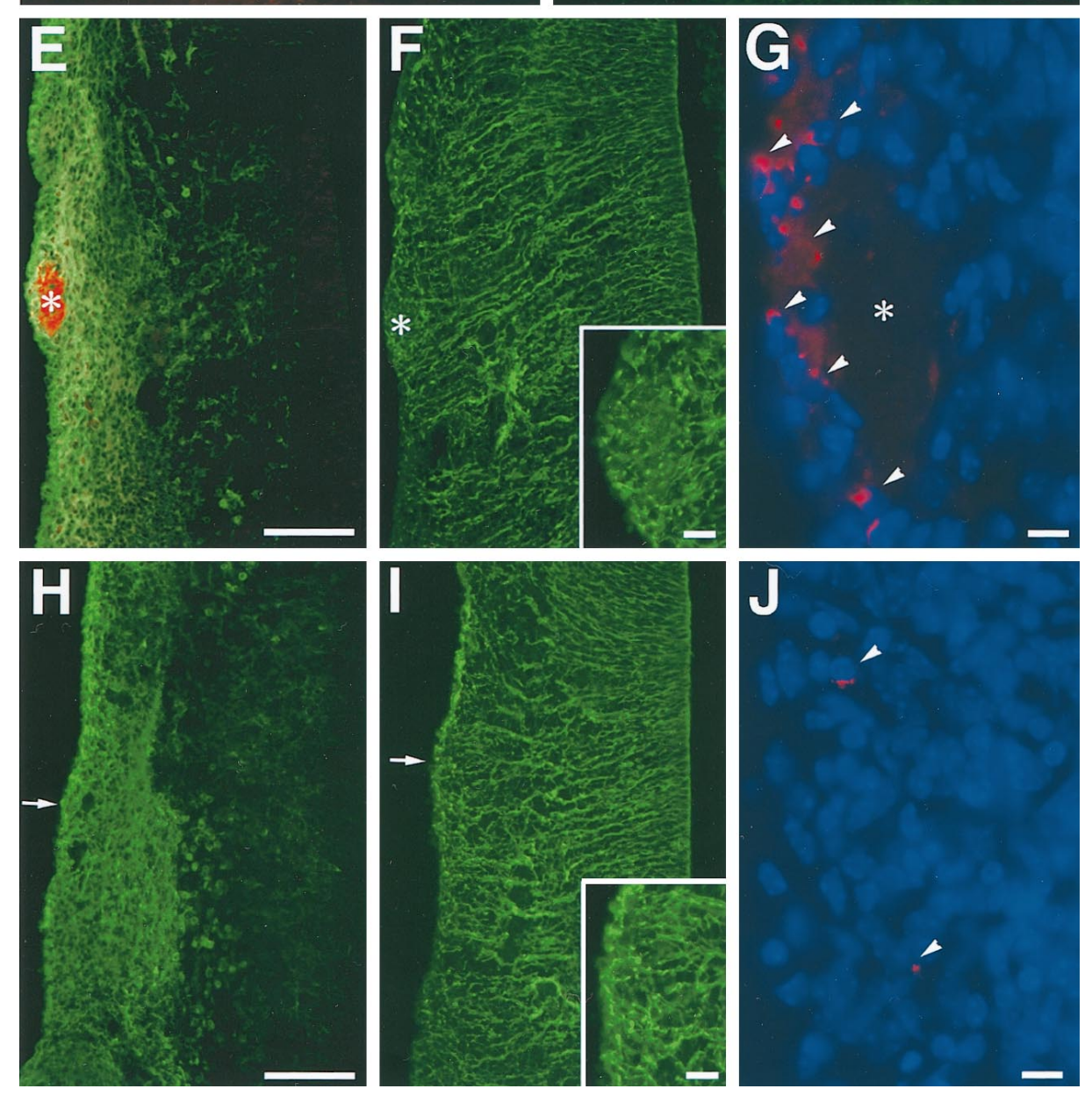
CNS. Recent studies have suggested that this assumption is correct. Subplate neurons, the early-generated neurons in the neocortex, might be the first example of scaffold cells in the mammal brain and have been shown to play roles in directing the pathway choice of thalamocortical axons (Ghosh et al., 1990; Ghosh and Shatz, 1992, 1993). The optic chiasma also contains a subset of early-generated neurons, which have been shown to be involved in retinal axon guidance (Easter et al., 1993; Sretavan et al., 1994, 1995). Recently, Cajal-Retzius cells in the hippocampus were suggested to play a role in guidance of entorhinohippocampal axons (Soriano et al., 1994; Del Río et al., 1997). The present demonstration of lot cells represented further evidence for the existence of guidepost cells in the mammalian CNS. Furthermore, the lot cells provided the first complete set of images of the scaffold that stretched across the entire tract region. Axonal guidance by early-generated neurons might be a more common phenomena than previously thought.

When mitral cell axons grew in the telencephalon in vivo, they chose the position juxtaposed to lot cell clusters and did not penetrate between lot cells except for the caudal end of the olfactory bulb. This spatial relationship might look puzzling if lot cells are assumed to guide mitral cell axons simply by producing factors that attract or support the axonal growth, as suggested by co-culture and lot cell ablation experiments. In fact, at most levels of the telencephalon, lot cells seemed to be the border beyond which mitral cell axons did not grow. Thus, we might need to consider a more complex form of interactions between lot cells and mitral cell axons during LOT formation.

In the developing piriform cortex, Derer et al. (1977) reported tangentially oriented cells in Golgi preparations, which they called horizontal fusiform cells. Although they did not discuss the close association of the cells with mitral cell axons, these cells appeared to be the lot cells observed in the present study. Horizontal cells were also reported in the adult piriform cortex, and they were suggested to function as inhibitory interneurons (Haberly, 1983; Haberly and Feig, 1983; Haberly et al., 1987). These observations might imply the persistence of some lot cells in adulthood after cessation of lot 1 antigen expression. Nevertheless, the sparse distribution of adult horizontal cells suggests that not all of the lot cells eventually constitute the adult piriform cortex. Similar disputes still continue regarding the fates of other early-generated neurons such as Cajal-Retzius cells and subplate neurons. Many recent studies, however, agree with the idea that the majority of these cells are transient neurons during development (Valverde and Facal-Valverde, 1988; Chun and Shatz, 1989; Derer and Derer, 1990; Del Río et al., 1995).

Recently, we found that collateral extension of mitral cell axons was directed by environmental cues around mitral cell axons (Hirata and Fujisawa, 1998). However, the relationship between lot cells and collateral extension was not as clear as that between lot cells and LOT formation. The lot cell redistribution into the collateral invasion areas did not precede the onset of collateral sprouting. Moreover, the majority of lot cells remained in the LOT position even after collateral spread. Therefore, we consider that occasional dispersion of lot cells into areas of collateral invasion is a passive movement of the cells and that lot cells do not play a major role in collateral extension of mitral cell axons. The heterochronic co-culture experiments also support the idea that LOT formation and collateral branching are directed by different mechanisms (Hirata and Fujisawa, 1998).

The molecular nature of guiding cues for mitral cell axons is obscure. Although Cajal-Retzius cells were shown to guide en- torhinohippocampal axons by expression of reelin (Del Río et al., 1997), this protein is evidently not a guiding molecule for mitral cell axons, because expression of reelin was not restricted to the LOT position. Moreover, neither anti-reelin mAb CR-50, which antagonizes reelin function (Ogawa et al., 1995; D'Arcangelo et al., 1997), nor mutation of the reelin gene (D'Arcangelo et al., 1995) affected LOT formation (Caviness and Sideman, 1972). Alternatively, lot1 antigen itself might be a candidate for the guiding molecule of mitral cell axons, if the subcellular localization of the antigen is interpreted as the association with Golgi apparatus and cell surface. Because mAb lot1 did not affect LOT formation in organotypic culture (data not shown), further analyses of lot 1 antigen are essential to determine the correlation between this antigen and LOT formation.

\section{REFERENCES}

Bayer SA (1983) ${ }^{3} \mathrm{H}$-thymidine-radiographic studies of neurogenesis in the rat olfactory bulb. Exp Brain Res 50:329-340.

Bentley D, Caudy M (1983) Pioneer axons lose directed growth after selective killing of guidepost cells. Nature 304:62-65.

Bentley D, Keshishian H (1982) Pioneer neurons and pathways in insect appendages. Trends Neurosci 5:354-358.

Brunjes PC, Frazier LL (1986) Maturation and plasticity in the olfactory system of vertebrates. Brain Res Rev 11:1-45.

Caviness Jr VS, Sideman RL (1972) Olfactory structure of the forebrain in the reeler mutant mouse. J Comp Neurol 145:85-104.

Chun JJM, Shatz CJ (1989) Interstitial cells of the adult neocortical white matter are the remnant of the early generated subplate neuron population. J Comp Neurol 282:555-569.

Condé F, Lund JS, Jacobowitz DM, Baimbridge KG, Lewis DA (1994) Local circuit neurons immunoreactive for calretinin, calbindin D-28k or parvalbumin in monkey prefrontal cortex: distribution and morphology. J Comp Neurol 341:95-116.

D'Arcangelo G, Miao GG, Chen SC, Soares HD, Morgan JI, Curran T (1995) A protein related to extracellular matrix proteins deleted in the mouse mutant reeler. Nature 374:719-723.

D’Arcangelo G, Nakajima K, Miyata T, Ogawa M, Mikoshiba K, Curran $T$ (1997) Reelin is a secreted glycoprotein recognized by the CR-50 monoclonal antibody. J Neurosci 17:23-31.

Del Río JA, Martínez A, Fonseca M, Auladell C, Soriano E (1995) Glutamate-like immunoreactivity and fate of Cajal-Retzius cells in the murine cortex as identified with calretinin antibody. Cereb Cortex $1: 13-21$

Del Río JA, Heimrich B, Borrell V, Förster E, Drakew A, Alcàntara S, Nakajima K, Miyata T, Ogawa M, Mikoshiba K, Derer P, Frotscher MES (1997) A role for Cajal-Retzius cells and reelin in the development of hippocampal connections. Nature 385:70-74.

Derer P, Derer M (1990) Cajal-Retzius cells ontogenesis and death in mouse brain visualized with horseradish peroxidase and electron microscopy. Neuroscience 36:839-856.

Derer P, Caviness Jr VS, Sidman RL (1977) Early cortical histogenesis in the primary olfactory cortex of the mouse. Brain Res 123:27-40.

Dodd J, Jessell TM (1988) Axon guidance and the patterning of neuronal projections in vertebrates. Science 242:692-699.

Easter Jr SS, Ross LS, Frankfurter A (1993) Initial tract formation in the mouse brain. J Neurosci 13:285-299.

Forehand CJ, Ezerman EB, Rubin E, Glover JC (1994) Segmental patterning of rat and chicken sympathetic preganglionic neurons: correlation between soma position and axon projection pathway. J Neurosci 14:231-241.

Ghosh A (1997) Axons follow reelin routes. Nature 385:23-24.

Ghosh A, Shatz CJ (1992) Involvement of subplate neurons in the formation of ocular dominance columns. Science 255:1441-1443.

Ghosh A, Shatz CJ (1993) A role for subplate neurons in the patterning of connections from thalamus to neocortex. Development 117:1031-1047.

Ghosh A, Antonini A, McCornnell SK, Shatz CJ (1990) Requirement for subplate neurons in the formation of thalamocortical connections. Nature 347:179-181.

Goodman CS, Shatz CJ (1993) Developmental mechanisms that generate precise patterns of neuronal connectivity. Neuron 10:77-98.

Haberly LB (1983) Structure of the piriform cortex of the opossum. I. 
Description of neuron types with Golgi methods. J Comp Neurol 213:163-187.

Haberly LB, Feig SL (1983) Structure of the piriform cortex of the opossum. II. Fine structure of cell bodies and neuropil. J Comp Neurol 216:69-88.

Haberly LB, Hansen DJ, Feig SL, Presto S (1987) Distribution and ultrastructure of neurons in opossum piriform cortex displaying immunoreactivity to GABA and GAD and high-affinity tritiated GABA uptake. J Comp Neurol 266:269-290.

Hinds JW (1972) Early neuron differentiation in the mouse olfactory bulb. I. Light microscopy. J Comp Neurol 146:233-252.

Hinds JW, Ruffett TL (1973) Mitral cell development in the mouse olfactory bulb: reorientation of the perikaryon and maturation of the axon initial segment. J Comp Neurol 151:281-306.

Hirata T, Fujisawa H (1997) Cortex-specific distribution of membranebound factors that promote neurite outgrowth of mitral cells in culture. J Neurobiol 32:415-425.

Hirata T, Fujisawa H (1998) Environmental control of collateral branching and target invasion of mitral cell axons during development. J Neurobiol, in press.

Kawakami A, Kitsukawa T, Takagi S, Fujisawa H (1996) Developmentally regulated expression of a cell surface protein, neuropilin, in the mouse nervous system. J Neurobiol 29:1-17.

Kennedy TE, Serafini T, de la Torre JR, Tessier-Lavigne M (1994) Netrins are diff usible chemotropic factors for commissural axons in the embryonic spinal cord. Cell 78:425-435.

Macrides F, Schneider SP (1982) Laminar organization of mitral and tufted cells in the main olfactory bulb of the adult hamster. J Comp Neurol 208:419-430.

Matsutani S, Senba E, Tohyama M (1988) Neuropeptide- and neurotransmitter-related immunoreactivities in the developing rat olfactory bulb. J Comp Neurol 272:331-342.

Ogawa M, Miyata T, Nakajima K, Yagyu K, Seike M, Ikenaka K, Yamamoto H, Mikoshiba K (1995) The reeler gene-associated antigen on Cajal-Retzius neurons is a crucial molecule for laminar organization of cortical neurons. Neuron 14:899-912.

Oi VT, Herzenberg LA (1981) Immunoglobulin producing hybrid cell lines. In: Selected methods in cellular immunology (Mishell BB, Shiigi SM, eds), pp 351-372. San Francisco: Freeman.
Schwob JE, Price JL (1984) The development of axonal connections in the central olfactory system of rats. J Comp Neurol 223:177-202.

Serafini T, Kennedy TE, Galko MJ, Mirzayan C, Jessell TM, TessierLavigne M (1994) The netrins define a family of axon outgrowthpromoting proteins homologous to C. elegans UNC-6. Cell 78:409-424

Shipley MT, McLean JH, Ennis M (1995) Olfactory system. In: The rat nervous system, Ed 2 (Paxinos G, ed), pp 899-926. San Diego: Academic.

Soriano E, Del Río JA, Martínez A, Supèr H (1994) Organization of the embryonic and early postnatal murine hippocampus. I. Immunocytochemical characterization of neuronal populations in the subplate and marginal zone. J Comp Neurol 342:571-595.

Sretavan DW, Feng L, Puré E, Reichardt LF (1994) Embryonic neurons of the developing optic chiasm express L1 and CD44, cell surface molecules with opposing effects on retinal axon growth. Neuron 12:957-975.

Sretavan DW, Puré E, Siegel MW, Reichardt LF (1995) Disruption of retinal axon ingrowth by ablation of embryonic mouse optic chiasm neurons. Science 269:98-101.

Sugisaki N, Hirata T, Naruse I, Kawakami A, Kitsukawa T, Fujisawa H (1996) Positional cues that are strictly localized in the telencephalon induce preferential growth of mitral cell axons. J Neurobiol 29:127-137.

Supèr H, Martínez A, Soriano E (1997) Degeneration of Cajal-Retzius cells in the developing cerebral cortex of the mouse after ablation of meningeal cells by 6-hydroxydopamine. Dev Brain Res 98:15-20.

Takagi S, Tsuji T, Amagai T, Takamatsu T, Fujisawa H (1987) Specific cell surface labels in the visual centers of Xenopus laevis tadpole identified using monoclonal antibodies. Dev Biol 122:90-100.

Takami S, Graziadei PC (1991) Light microscopic Golgi study of mitral/ tufted cells in the accessory olfactory bulb of the adult rat. J Comp Neurol 311:65-83.

Tessier-Lavigne M, Goodman CS (1996) The molecular biology of axon guidance. Science 274:1123-1131.

Theiler K (1989) The house mouse: atlas of embryonic development. New York: Springer.

Valverde F, Facal-Valverde MV (1988) Postnatal development of interstitial (subplate) cells in the white matter of the temporal cortex of kittens: a correlated Golgi and electron microscopic study. J Comp Neurol 269:168-192. 